\title{
A HISTORY OF THE ENTOMOLOGY AND PLANT PATHOLOGY LABORATORIES ON THE NIAGARA PENINSULA
}

I9II/1960

LIBRARY

CANADA AGRICULTURE

G.G. Dustan and R.S. Willison

PROPERTY OF LIBRARY

DEPARTMENT OF AGRICULTURE, OTTAWA Lent to................. PLEASE RETURN AL 32

\section{1 \\ C 212}

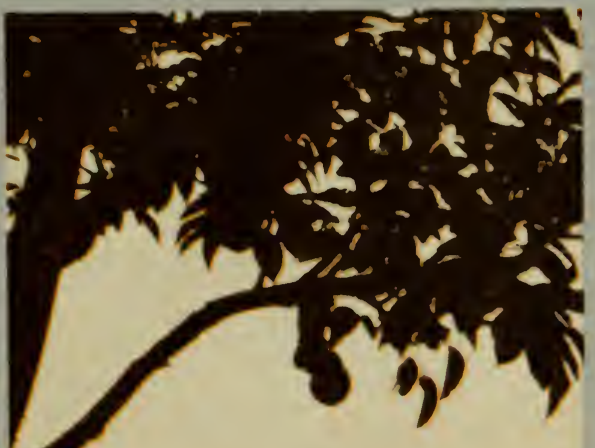

HS no 4 


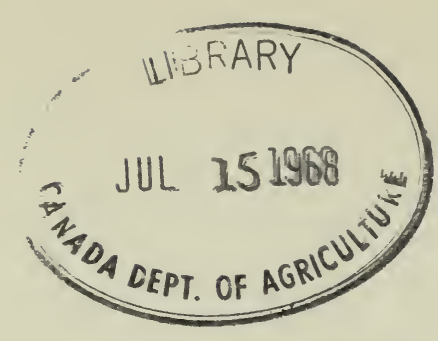




\section{A HISTORY OF THE ENTOMOLOGY AND PLANT PATHOLOGY LABORATORIES ON THE NIAGARA PENINSULA 1911-1960}

G.G. Dustan

R.S. Willison

1968

Historical Series-Number 4

CANADA DEPARTMENT OF AGRICULTURE 


\section{Crown Copyrights reserved}

Available by mail from the Queen's Printer, Ottawa, and at the following Canadian Government bookshops:

HALIFAX

1735 Barrington Street

MONTREAL

AEterna-Vie Building, 1182 St. Catherine Street West

OTTAWA

Daly Building, Corner Mackenzie and Rideau

TORONTO

221 Yonge Street

WINNIPEG

Mall Centre Building, 499 Portage Avenue

VANCOUVER

657 Granville Street

or through your bookseller

Price $\$ 2.00$ Catalogue No. A54-2/4

Price subject to change without notice

ROGER DUHAMEL, F.R.S.C.

Queen's Printer and Controller of Stationery

Ottawa, Canada

1967 


\section{CONTENTS}

Establishment of Laboratories at Vineland and St. Catharines ..... 5

Development of the Entomology Laboratory at Vineland ........... 7

The Plant Pathology Laboratory at St. Catharines .................... 21

Amalgamation of Vineland and St. Catharines Laboratories ........ 35 


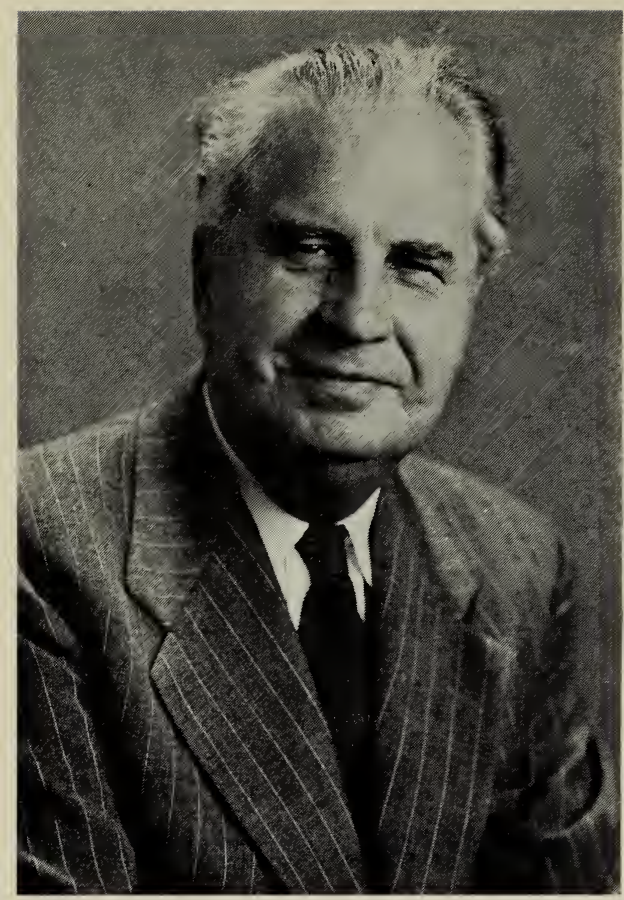

W. A. Ross (1890-1961), Officerin-Charge of the Fruit Insect Laboratory, Vineland, Ontario, from 1911 to 1947.

G. H. Berkeley (1894-1965), Officerin-Charge, Dominion Laboratory of Plant Pathology, St. Catharines, Ont., from 1923 to 1959.

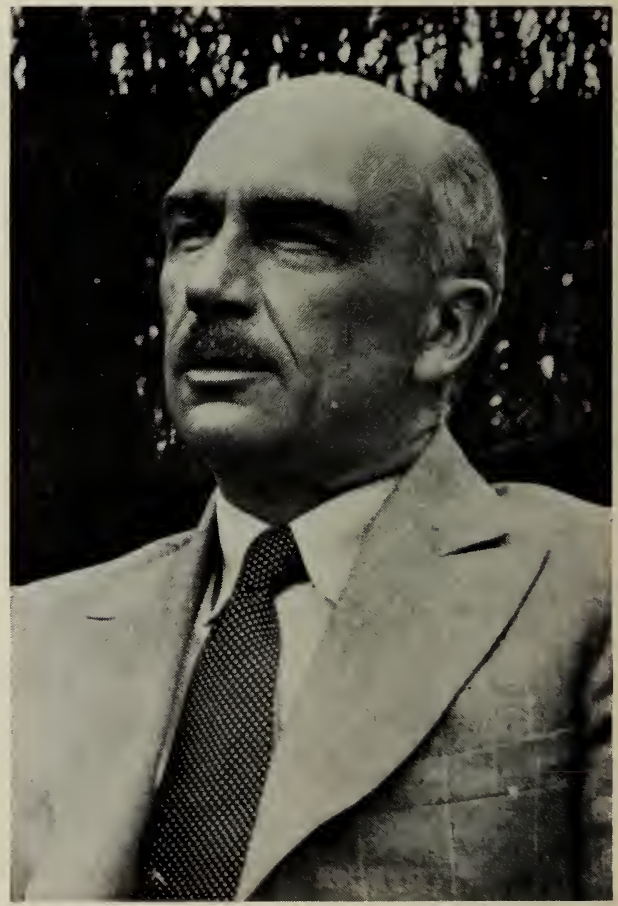




\section{FOREWORD}

For almost half a century the federal government carried out research in entomology at the Ontario Horticultural Experiment Station, Vineland, Ontario, while research in plant pathology was conducted at St. Catharines. Throughout this period two small laboratories remained autonomous units and there was little attempt to integrate their programs. In 1960, the two laboratories were combined into one administrative unit under a single director. However, physical integration had to await completion of new research facilities at Vineland, and it is only in 1967 that the old laboratories at Vineland and St. Catharines are to disappear.

The early days of the laboratories and the personalities of some of the early scientists who pioneered research on insects and diseases of horticultural crops on the Niagara Peninsula is fascinating history.

With new research facilities, a relatively young scientific staff and a new era of research, the past is easily forgotten. To prevent this, I have asked two of our older scientists to turn back the years, record here the history of these laboratories, and recall their impressions of the characters who played such an important role in agricultural science on the Niagara Peninsula so many years ago.

W. B. Mountain, Director

Research Station

Vineland, Ontario

June 1966 


\section{ESTABLISHMENT OF LABORATORIES AT VINELAND AND ST. CATHARINES}

The Dominion Entomological Laboratory, later to become the Fruit Insect Laboratory, was established in 1911 at Vineland, Ontario, in what older entomologists refer to as the good old nicotine sulphate, lime sulphur, lead arsenate days. This field laboratory was one of the first four established by the old Division of Entomology of the Experimental Farms Branch, Dominion Department of Agriculture. The others were at Bridgetown, Nova Scotia (1909), Agassiz, British Columbia (1911), and Fredericton, New Brunswick (1912).

From the beginning, the Laboratory was closely associated with the Ontario Horticultural Experiment Station. The staff had offices in the Station building for fourteen years. The station also provided the Laboratory with orchard plots and assistance in applying insecticides until 1958, when the federal government purchased an orchard at Jordan Harbour two and a half miles away.

In 1912, soon after the Entomology Division had set up its laboratory at Vineland, the Botany and Plant Pathology Division of the Department followed suit with another field laboratory, also in the Niagara district. This latter division of the Experimental Farms Branch had been created in 1909 to take over the botanical work of the Department, previously done in desultory fashion under the auspices of the Entomology Division. To assert its newly won independence, the Botany Division located its laboratory not at Vineland but in St. Catharines, on the east bank of the Welland ship canal then being built. Thus came into being the firstborn Dominion Laboratory of Plant Pathology.

For over forty years there was rivalry between the Laboratories at Vineland and St. Catharines. This fortunately mellowed with the passing of years, and despite the separation of seven miles and friendly competition, the two Laboratories cooperated on many problems of mutual interest.

We sometimes hear younger scientists say there are no characters today as there used to be. Be that as it may, W. A. Ross, Officerin-Charge at Vineland from 1911 to 1947, and G. H. Berkeley, Officerin-Charge at St. Catharines from 1923 to 1959 , definitely fell into the character class.

Both had strong personalities. Ross had a domineering manner and what seemed to be an almost naive belief that his views and actions would be accepted without question by his associates. A few diffident members of his staff resented this and hesitated to press for what they wanted. However, most of us soon learned that, if our views were sound, a little persistence would soon convince him and win his whole-hearted support. Behind his sometimes brusque manner, he was essentially a kindly man who was very loyal to his staff. 
Berkeley also had strong views and very emphatic ways of expressing them. Discussion of policy between the two Officers-in-Charge often progressed no further than: "Oh no, Berk, we'll do it this way," and, "But dammit, Bill, my boys won't go along with that and I won't either." There is little doubt that the conflicting personalities of Ross and Berkeley had much to do with the long life of separate laboratories for studying insects and plant diseases on the Niagara Peninsula. 


\section{DEVELOPMENT OF THE ENTOMOLOGY LABORATORY AT VINELAND}

THE EARLY YEARS

William A. Ross, a Scotsman who came to Canada to study agriculture, was the first entomologist in charge at Vineland. He came to the Laboratory as soon as he received his B.S.A. degree in entomology from the Ontario Agricultural College. Ross worked alone for seven years. At that time he was concerned primarily with insects of fruits and vegetable crops, but he also studied other insect pest problems in the area. His first interest was aphids of fruit crops. This led to the Laboratory's first publication - on aphids occurring on apple trees - which appeared in 1917. A more comprehensive paper in 1918 dealt with the black cherry aphid, and another paper in 1918 described the pear psylla and its damage.

Very little was known at that time about many of the fruit pests in Ontario and so the scope of the early papers was quite general. In them Ross gave descriptions and life histories of pests, and discussed host plants, types of injury, parasites, predators and chemical control measures.

Expansion of the Laboratory staff started in 1918 with the appointment of William Robinson and C. H. Curran. Curran did not find economic entomology to his liking and left after one year. Eventually he became one of the leading American dipterists. Robinson, who stayed three years, studied the pear psylla, the European red mite and the potato leaf hopper. Robinson was an outstanding photographer, and many of his photographs are still used to illustrate departmental publications.

W. G. P. Garlick joined the staff in 1921 to study insects of small fruits and, in later years, the chemical and natural control of apple pests. J. A. Hall, who came in 1922, worked on the rose chafer; and A. J. Graham, who was with us from 1924 to 1926, started an investigation of the codling moth. When Graham resigned, this last project was taken over by Hall.

From the beginning, the staff concentrated on studying the life histories and habits of the various fruit pests of the area. One by one, all the important insect pests were studied in detail: the pear psylla, codling moth, Oriental fruit moth, grape berry moth, peach tree borers and plum curculio, to mention but a few. The information obtained was widely published and has remained the basis for control recommendations throughout the years.

The entomologists established close contact with fruit growers and conducted many experiments in their orchards. In return, during the Laboratory's first fifteen years, and, indeed, for many years 
thereafter, some of the staff spent nearly a quarter of their time on extension work. This involved correspondence with growers and visits to their orchards, diagnosis of pest problems, and recommendations for control, not to mention the talks that Ross and others frequently gave at growers' meetings.

From one to three student assistants worked at the Laboratory each summer from about 1929. They rendered valuable service, especially in the routine counting for ecological studies of what amounted to probably millions of mites. Some of the students went on to become physicians, others to teach high school; some of them joined the technical staffs of insecticide companies and a few even became housewives.

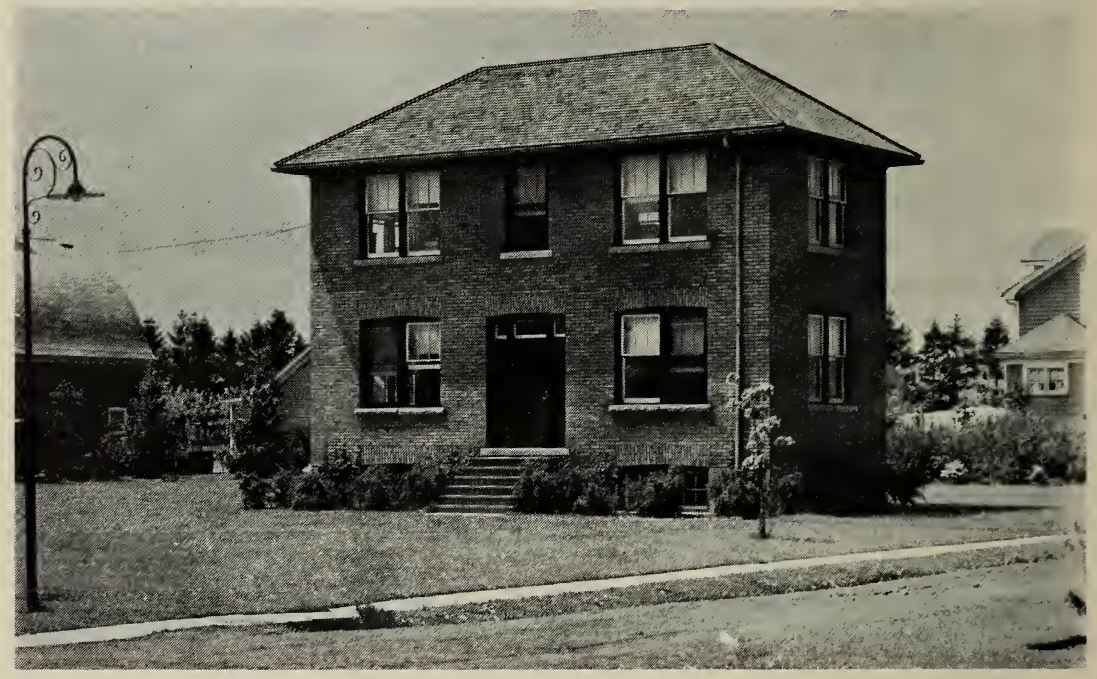

The Department's first Fruit Insect Laboratory at Vineland, built in 1925.

\section{THE LABORATORY GETS ITS OWN BUILDING}

The Vineland staff gradually outgrew its accommodation in the Horticultural Experiment Station building and in 1925 the Canada Department of Agriculture built its own two-storey, 17- by 35-foot laboratory, still on the grounds of the Horticultural Research Institute of Ontario. The new laboratory had two offices on the ground floor and one room above. At peak occupancy this upstairs room housed seven men, all trying, none too successfully towards spring, to keep out of each other's hair. An addition to the building in 1934, built partly by the junior staff, doubled its size and provided eight offices, a library, a chemistry laboratory and a basement workroom. It is worth noting that when the addition was made, in the depths of the Depression, funds were so scarce that it was 


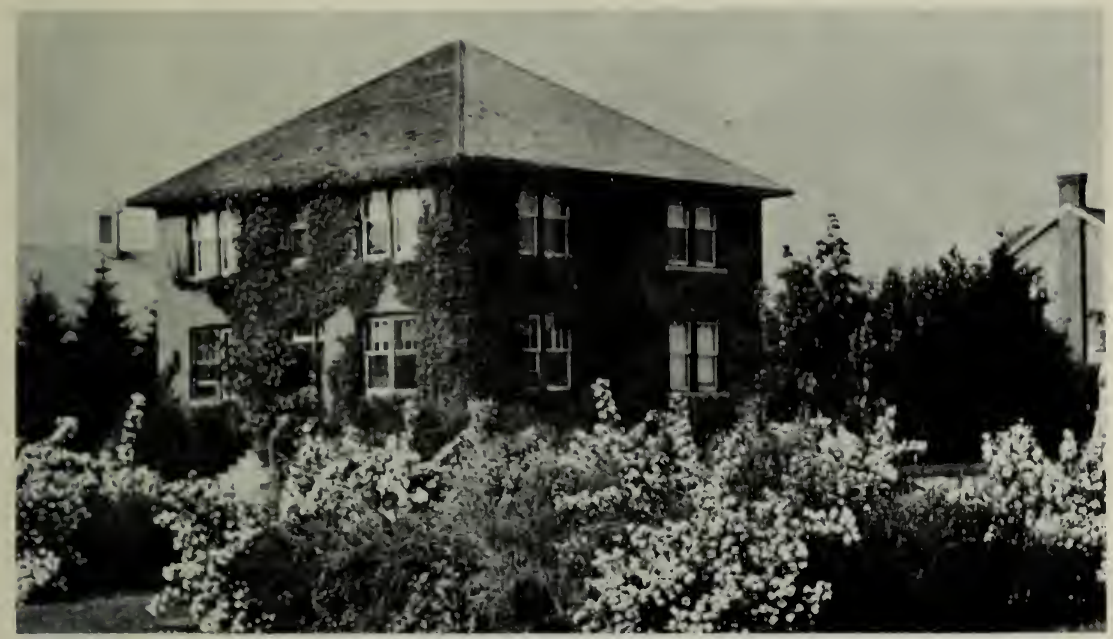

The Fruit Insect Laboratory at Vineland after the building was enlarged in 1934.

built with supply money scrounged from headquarters, and odd purchases of lumber, bricks and other bits and pieces. Its construction was accompanied by a flood of letters from the Dominion Entomologist, the gist of each being: "This is positively the last bill we can pay."

Within a few years, this building, too, became inadequate as the staff continued to grow. Eventually, every available corner and niche was overcrowded with equipment and supplies, not to mention research officers, technicians and student assistants.

\section{ORIENTAL FRUIT MOTH BRINGS ESTABLISHMENT OF ST. DAVID'S FIELD STATION}

The discovery of the Oriental fruit moth in a peach orchard at St. David's ( 18 miles from Vineland) in the fall of 1925, and the realiaztion of its threat to the peach industry, marked a turning point in the operation of the Laboratory. Before this, each officer worked almost entirely alone on one or more pests. However, the fruit moth, for which no control was known, required an expanded, cooperative effort.

Thomas Armstrong, who came from Charlie Petch's laboratory at Hemmingford, Quebec, started an extensive study of the life history of the moth in the insectary at Vineland in 1926.

In 1927, a field station of the Laboratory was established at St. David's in the 75-acre peach orchard where the heavy infestation of the fruit moth had been discovered. The first building at the field station was a 6- by 6 -foot shed which you entered by crossing the edge of a manure pile on a plank. Next year James Calvert, 


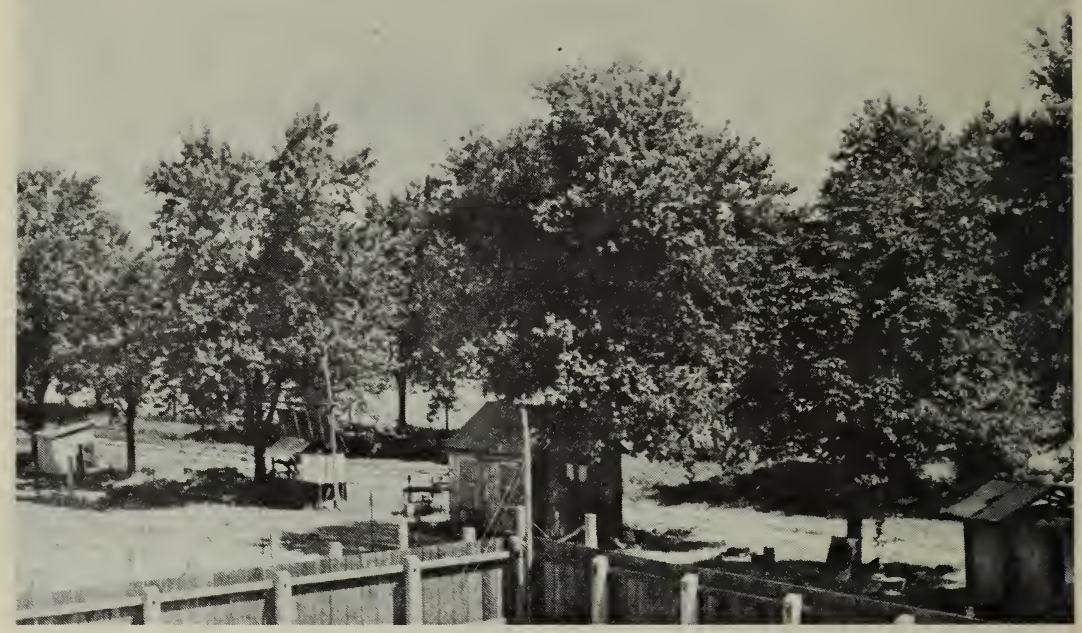

St. David's field station, in the peach orchard where the Oriental fruit moth was discovered in Canada in 1925.

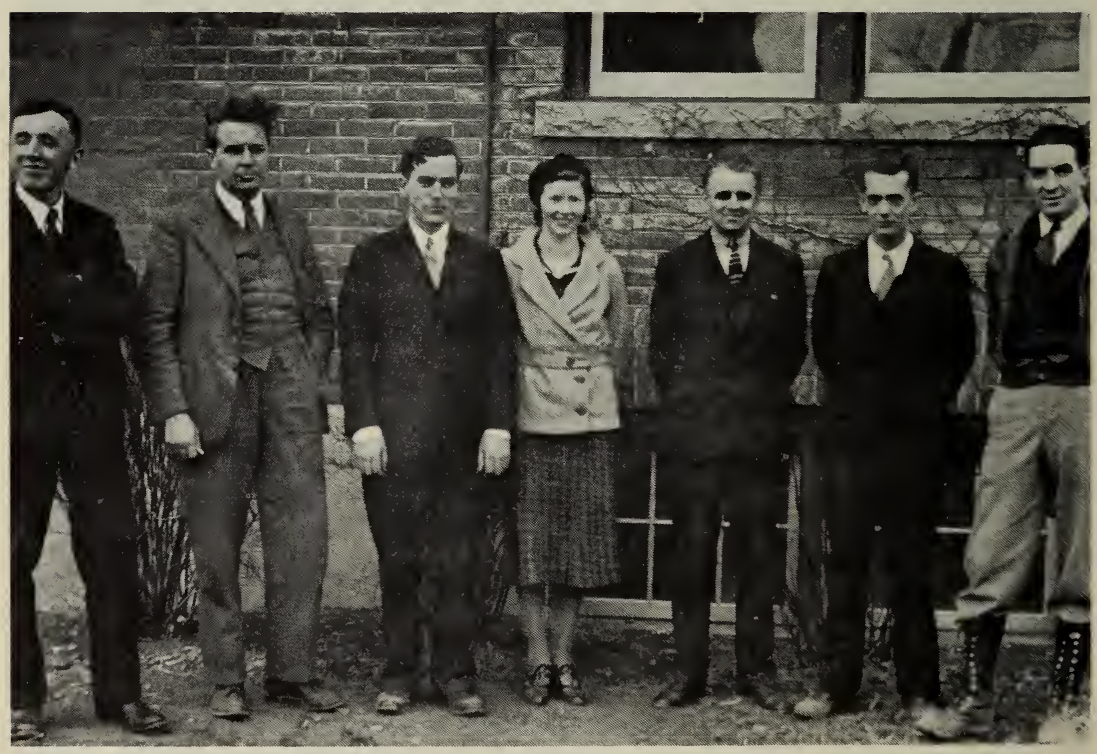

The staff of the Fruit Insect Laboratory in 1930. From left to right: P. I. Bryce, W. A. Ross, D. F. Patterson, Miss Della Myers, Thos. Armstrong, W. L. Putman, G. G. Dustan. (absent, W. G. Garlick). 
owner of the orchard, constructed at his own cost another, and by comparison palatial, shed about 9 by 12 feet in size with two benches running from end to end. This, with two or three "openair" insectaries, housed many entomologists and student assistants for more than half of each year until the end of the 1934 season.

At the establishment of the St. David's field station, the Laboratory was still in the Model $\mathrm{T}$ days. Bill Ross started his career on a motorcycle. Present members of the staff still regret missing this stirring sight because Ross was singularly lacking in mechanical skill. The motorcycle was followed by several Model $\mathrm{T}$ Fords, and one of the favorite pastimes of the staff was to watch Ross lurch one of these old heaps out of the driveway anidst a shower of gravel thrown out by the spinning wheels.

Peter Bryce went to St. David's in 1927. In the same year, G. G. Dustan was employed by the Ontario Fruit Branch to work on the Oriental fruit moth under the general direction of Professor Lawson Caesar and was seconded to St. David's. D. F. Patterson joined the St. David's group in 1928 and W. L. Putman in 1931. This team, together with Armstrong at Vineland, studied all phases of the Oriental fruit moth problem, including the moth's life history and habits, the effects of weather, seasonal abundance, damage, and - unsuccessfully because DDT was not yet available - chemical control.

An amusing incident in the old laboratory at St. David's concerns the man who appeared at the door and asked where he could find the owner of the orchard. Bill Putman's speech difficulty prevented a ready reply, though he tried. Dusty then came to the rescue by announcing that he was deaf and would the man please repeat his question more loudly. This was too much-the poor man took off frantically for his car and departed, thinking, no doubt, he had left a real bughouse!

\section{FRUIT MOTH PARASITE INVESTIGATIONS}

The realization that parasites could play an important role in suppressing the Oriental fruit moth soon led to close cooperation with officers of the Dominion Parasite Laboratory, Belleville, Ontario. Investigation of the moth's native parasites was started in 1928 by Chester Smith and was continued until 1935 by L. J. Briand, W. E. van Steenburgh and H. R. Boyce-all in cooperation with the St. David's group. The introduction from New Jersey and the successful establishment in 1929 and 1930 of the valuable braconid parasite Macrocentrus ancylivorus was the chief result of the parasite studies. Boyce was seconded to Vineland in 1938 and continued parasite studies there until 1945.

The work of the entomologists was generally well received by the fruit growers and some had great faith in the "bug-men." A few, 
however, took some convincing. James Calvert, the hard-headed businessman who owned the St. David's orchard, was one of the latter. Dr. van Steenburgh, who tried controlling the fruit moth with mass liberations of the minute parasite Trichogramma, hailed Calvert one day and announced: "I have good news for you, Mr. Calvert, I've just released thirty million Trichogramma in your orchard."

Calvert's sole response after fixing van Steenburgh with a beady stare was: "Who the hell counted them?"

Though Macrocentrus and other parasites soon became relatively abundant, they did not give a consistently high degree of control or prevent outbreaks of the Oriental fruit moth. Because of this, Bill Putman, with some assistance from Dustan, carried out a fiveyear ecological study in four representative orchards on the Niagara Peninsula. This study produced much interesting information but it failed to reveal the factors regulating the population density of the moth so that reliable predictions could be made.

\section{SPRAY CALENDARS}

The Ontario Spray Service, which has issued annual spray calendars since the early 1920 's, depended heavily on the findings and advice of both the Vineland and St. Catharines Laboratories.

The increase over the years in the complexity of control measures for fruit insects and diseases is well illustrated by a comparison of annual meetings of the spray calendar revision committee in the 1920 's and 1960's. Ross once described a typical early meeting of the entire committee of himself, Gar Berkeley, Professor Lawson Caesar and Professor Eaton (Gander) Howitt. After Ross and Howitt had befouled the Gander's office with their pipes and told a few stories, one would say: "Well, we had better change '1927' to '1928.'" Then, unless one of them had another story, that completed the revision meeting for another year. At that time the spray calendar for apples listed exactly three insecticides and three fungicides: lead arsenate, calcium arsenate, nicotine sulphate, Bordeaux mixture, lime sulphur, and dry-mix (wettable) sulphur.

By contrast, in the mid-1960's, spray calendars for fruit crops in Ontario list forty-three pesticides, and for apple pests alone, nineteen insecticides or miticides and thirteen fungicides. The spray committee for fruit crops is broken into four sub-committees with a total of twenty-two members. Also, representatives of other interested groups such as extension specialists, the Pesticide Section of the Plant Products Division, the Food and Drug Directorate, and the pesticide industry attend the annual two-and-a-half-day revision meeting. However, despite the growth of the committee, members of the Vineland Laboratory are still responsible for the major share of the recommendations for the control of insects and mites on fruit crops. 


\section{SIMCOE SUBSTATION ESTABLISHED}

To meet the needs of the apple-growing industry, Allan Hall was transferred in 1929 from Vineland to Simcoe, Ontario, where he was given an office in the Agricultural Representative's building. Our Department could not provide funds for a building during the Depression, but in 1935 the Norfolk Fruit Growers Association built a three-room, cottage-type laboratory on half an acre of land for Hall's use. A few years later the deed to this property was turned over at no cost to the Department of Agriculture.

At first the Simcoe Laboratory was a substation of the Vineland Laboratory but later was operated for a few years as an independent unit. Still later, on Hall's retirement in 1958, it returned to substation status. A. Hikichi was Hall's first permanent assistant, coming on staff in 1951. When Hall retired Hikichi became Officer-in-Charge of the substation.

Along with their research, notably on apple maggot and leaf rollers attacking apple, and concentrate spraying for apple pest control, both Hall and Hikichi devoted much of their time to extension work with the growers in Norfolk County. Later, the assignment of a horticultural extension specialist to that area relieved Hikichi of most of that work.

\section{EQUIPMENT}

Throughout the Depression and during most of the Second World War, the entomologists were, of necessity, "haywire" carpenters and mechanics. Even adequate tools were not available.

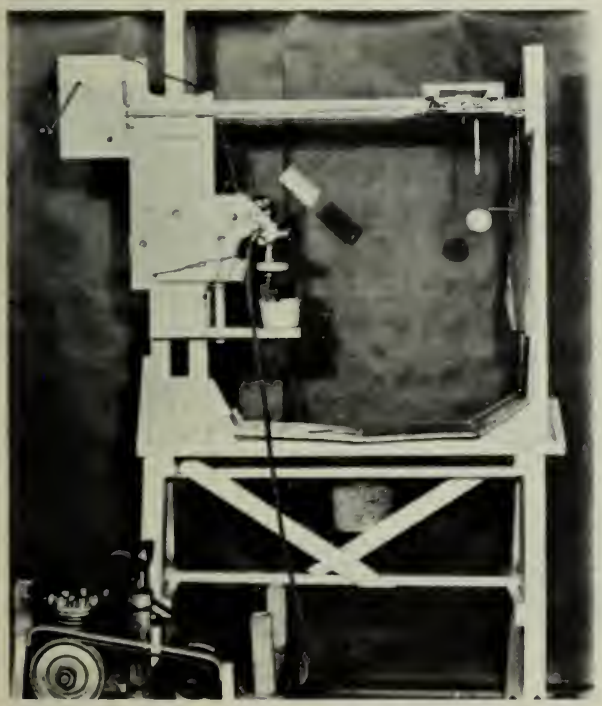

The Putman semi-automatic spraying frame. 


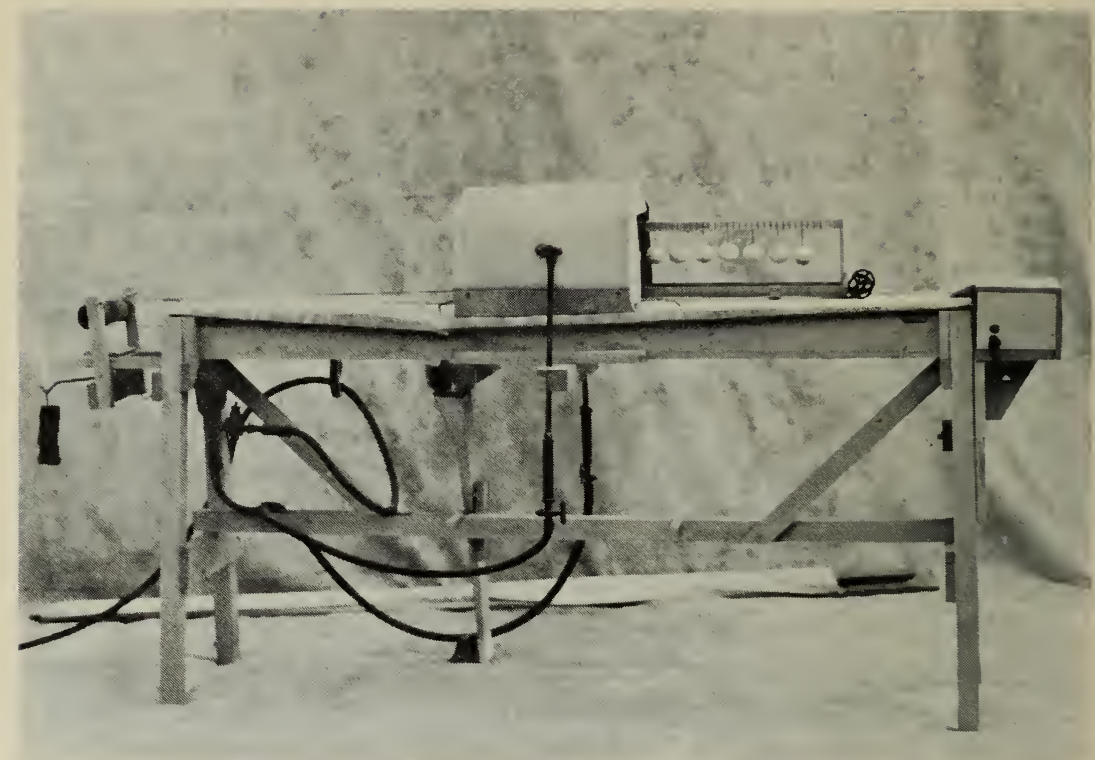

Device for weathering spray deposits on apples, invented by Putman.

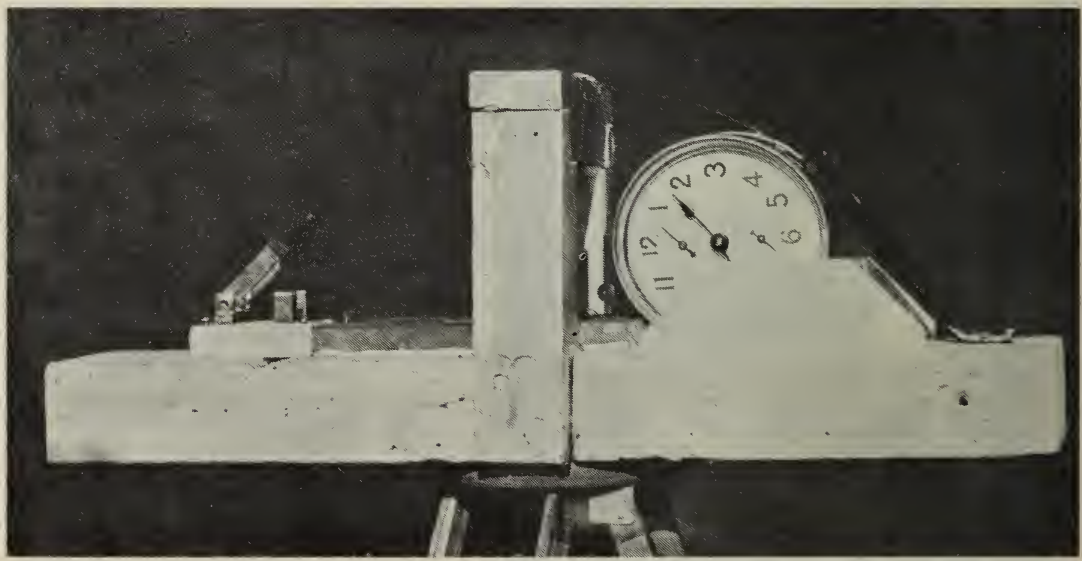

Dustan's automatic switch timer. 


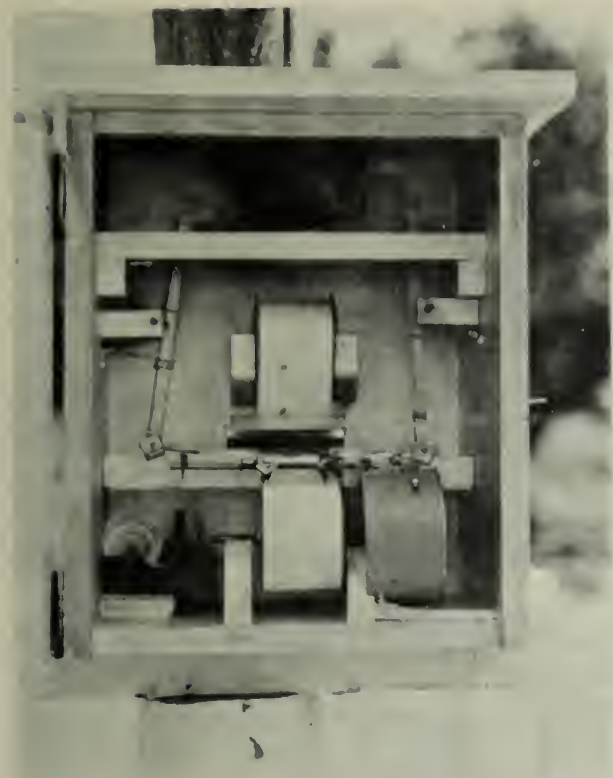

The interior of Dustan's wind direction recorder.

For years at the Vineland Laboratory, hand saws, planes, chisels and hammers were all we had to build rearing cages, cabinets and other needed gadgets. Younger entomologists are amazed or horrified (it is difficult to tell which) when we tell them what we had to do to improvise apparatus-some of it quite complicatedwhen funds just were not available for scientific equipment. Old rattraps, phonograph motors, alarm clocks, and parts of old typewriters were among the most useful items. These were supplemented with choice bits of pipe, wheels, springs and other odds and ends salvaged during our dump-picking expeditions to the Experiment Station garbage dump.

One of the weirder-looking inventions was "The Putman Semiautomatic Spraying Frame." Made from a phonograph motor, a camera tripod leg and sundry bits of wood and metal, it turned suspended apples at precise, variable speeds in a spray stream, and rang a bell at each revolution.

With a rat-trap and alarm clock, Dustan made another appliance which threw an electric switch at any desired hour. This precision instrument, much to the disgust of Dr. van Steenburgh who daily predicted its failure, faithfully shut off a fan near sunset for several weeks.

Perhaps the most complicated of the instruments made in the 1930 's was a wind-direction recorder which gave a continuous and 
remarkably accurate record in ink on a moving strip of addingmachine paper. Among its parts were a bicycle axle, an old clock, recording pens made from sheet metal (tin cans) and parts of an old typewriter.

Two photographic enlargers and four temperature-controlled cabinets, hand-made in the basement between 1930 and 1948, were still in use when the old laboratory gave way to the new in 1967 .

\section{CHANGE TO FRUIT INSECT LABORATORY}

The Fruit Insect Unit of the Division of Entomology was established in 1938 and about that time the Dominion Entomological Laboratory became known as the Fruit Insect Laboratory. Ross became head of the Unit but remained at the Vineland Laboratory until 1948, when he was finally persuaded to move to headquarters at Ottawa.

Late in 1939, the Laboratory built a greenhouse of seven small compartments and a connecting house, attached to the greenhouses of the Ontario Horticultural Experiment Station. In December of that year, G. G. Dustan left the Ontario Service and joined the staff of the Fruit Insect Laboratory to study insects of greenhouse ornamental crops. During the war, this project was gradually changed to a study of insecticides, in an attempt to find substitutes for materials in short supply.

\section{DDT AND OTHER PESTICIDES MAKE THEIR APPEARANCE}

The introduction of DDT for civilian use in 1943 marked the beginning of another era at the Vineland Laboratory. We gave DDT extensive trials in the greenhouse, trying it on several test insects and mites, and using, at the start, wettable formulations that we made from the technical material. As Canada obtained DDT for civilian testing several months before the United States, our initial trials resulted in the first report published in North America (1944) on the effects of DDT on plant-feeding insects. Also, we were the first to report the material's lack of toxicity to the two principal orchard mites. This finding had far-reaching implications on pest control in orchards, as DDT aggravated the mite problem by killing many of the predators.

Before the introduction of DDT, control of the codling moth on apples in southern Ontario had become so poor, because of the moth's resistance to lead arsenate, that many apple orchards were turned over to other crops. Also, at that time there was no effective control for outbreaks of the Oriental fruit moth on peaches. However, with DDT the Laboratory quickly worked out effective spray programs to control both these pests.

DDT was soon followed by a flood of other new organic insect- 
icides and miticides, all of which were tested extensively in greenhouse and orchards. Between 1945 and 1958 the Laboratory was the central point in Canada for the initial laboratory and field testing of new materials. This work, notably by Armstrong on miticides, resulted in a series of publications for the information and guidance of other entomologists in Canada. It was largely this research that led Ross to work for the establishment of the Pesticide Research Institute at London, Ontario.

The organophosphorus insecticides such at TEPP, parathion, malathion and Guthion were soon found by the Laboratory to be excellent for controlling many important orchard pests besides the codling moth and the Oriental fruit moth, notably the pear psylla, grape leaf hoppers, the European red mite, aphids, the plum curculio and the red-banded leaf roller.

\section{STAFF CHANGES AND NEW PROJECTS IN THE POST-WAR YEARS}

In 1947, one year before Ross transferred to Ottawa, G. G. Dustan was appointed Officer-in-Charge of the Vineland Laboratory. $\mathrm{He}$ retained this position until the amalgamation with the Laboratory of Plant Pathology in 1959. Dustan had returned to full-time investigations of the Oriental fruit moth in 1946 during a severe outbreak of the pest. He was assisted in this work by Charlie Simpson and, after 1947, by Cameron Miller.

The first technicians to join the staff were Charlie Simpson, in 1947, and Harvey Wagner a year later. The latter went to the Simcoe substation to assist Hall and later Hikichi. Eventually, these two senior technicians and the late John de Ronde took over most of the testing of new pesticides for the Vineland, Simcoe and St. Catharines Laboratories.

The Fruit Insect Laboratory early recognized the disadvantages and potential hazards of the new pesticides, especially their destruction of beneficial predators and their toxicity to applicators and consumers. Also, the comparatively early appearance of resistance of some pests to specific materials, notably mites to parathion and some other organophosphates, emphasized another serious aspect of pest control. With these matters in mind, and with the increase in staff after the war, the Laboratory initiated in the 1940's and 1950's several long-term studies on the over-all effects of pesticides, including fungicides, on orchard fauna. Putman, with the early assistance of J. H. H. Phillips, who joined the entomology staff in 1947 , and D. H. C. Herne who came in 1952, studied the effects of pesticides on the fauna of peach orchards, with special reference to predators and their habits and abundance. This productive project showed that if an insecticide relatively innocuous to predators of orchard mites could be found for the control of the Oriental fruit 
moth, mites would not be a commercial problem in peach orchards. As yet, however, no such material is known.

During this period, Tommy Armstrong made notable contributions through his studies of the biology and control of the peach tree borers, the plum curculio, the pear psylla, and the codling moth on pear.

Recognizing the importance of the "integrated" control of apple pests achieved in Nova Scotia by a minimum use of insecticides and the choice of pesticides, including fungicides, that were the least destructive to beneficial parasites and predators, W. G. Garlick conducted a five-year (1950-1955) faunal study in an apple orchard at the Experiment Station. His chief finding was that, in an area like the Niagara Peninsula, where the codling moth is two-brooded and very destructive under favorable weather conditions, natural control factors (largely predators and parasites) were not sufficient to give commercial control of this serious pest in the absence of highly toxic insecticides such as DDT, parathion and Guthion. As in peach orchards, mites are not a problem if these materials are not used, but until selective insecticides are available apple growers must rely primarily on present chemical controls.

Dr. J. H. H. Phillips, who had worked out of the St. Catharines Laboratory for several years studying the insects of sour cherry orchards and their possible relation to the transmission of cherry yellows virus, moved to the Vineland Laboratory in 1954 to investigate scale insects and the tarnished plant bug. John de Ronde, a senior technician, assisted Phillips from 1958 to 1960.

Dr. J. A. George joined the staff of the Entomology Laboratory in 1954 and, in close cooperation with Tom Davidson at St. Catharines, continued the investigation of cherry yellows. During the next six years, these two men demonstrated that the virus was transmitted through pollen carried by bees. In 1960, George started a continuing study of the use of the sterile male technique and the utilization of the sex lure in controlling the Oriental fruit moth.

Dr. Grant Robinson spent one year (1952-53) at the Laboratory assisting Putman in his peach faunal studies. Don Herne, arriving in 1952, also assisted Putman and then, after Armstrong retired in 1958, assumed direction of miticide studies in the field and laboratory.

In 1958, Dr. Robert Fisher transferred from the Pesticide Research Institute, London, Ontario, to the Vineland Laboratory, where he specialized in insecticide studies. A notable contribution was his discovery of the insecticidal and fungicidal properties of polybutenes.

Dr. A. B. Stevenson was appointed in 1959 and started an investigation of the distribution, economic importance and control of the grape phylloxera. His work on this difficult project gave the 
grape and wine industries the guidance they needed to deal with the pest. Stevenson also conducted studies on bird damage to grapes, in close cooperation with personnel of the Canadian Wildlife Service. The Laboratory was fortunate in having fruit and vegetable extension specialists located nearby. These men, first attached to the Experiment Station and, after 1951, to the Extension Service of the Ontario Department of Agriculture, increasingly relieved the research staff of the Laboratory of most of the diagnostic and advisory services to the fruit growers of the area. Also, they provided the Laboratory with valuable information on insect and disease conditions on the Niagara Peninsula and in other fruit-growing areas of Ontario.

The Fruit Insect Laboratory has always had a close and pleasant association with the insecticide industry. This has been mutually beneficial. The Laboratory has tested hundreds of new chemicals, and the industry, for its part, has assisted in many phases of pesticide research, such as analyzing plant material for toxic residues, providing special formulations of experimental compounds, and supplying information on the performance of materials in other areas. 


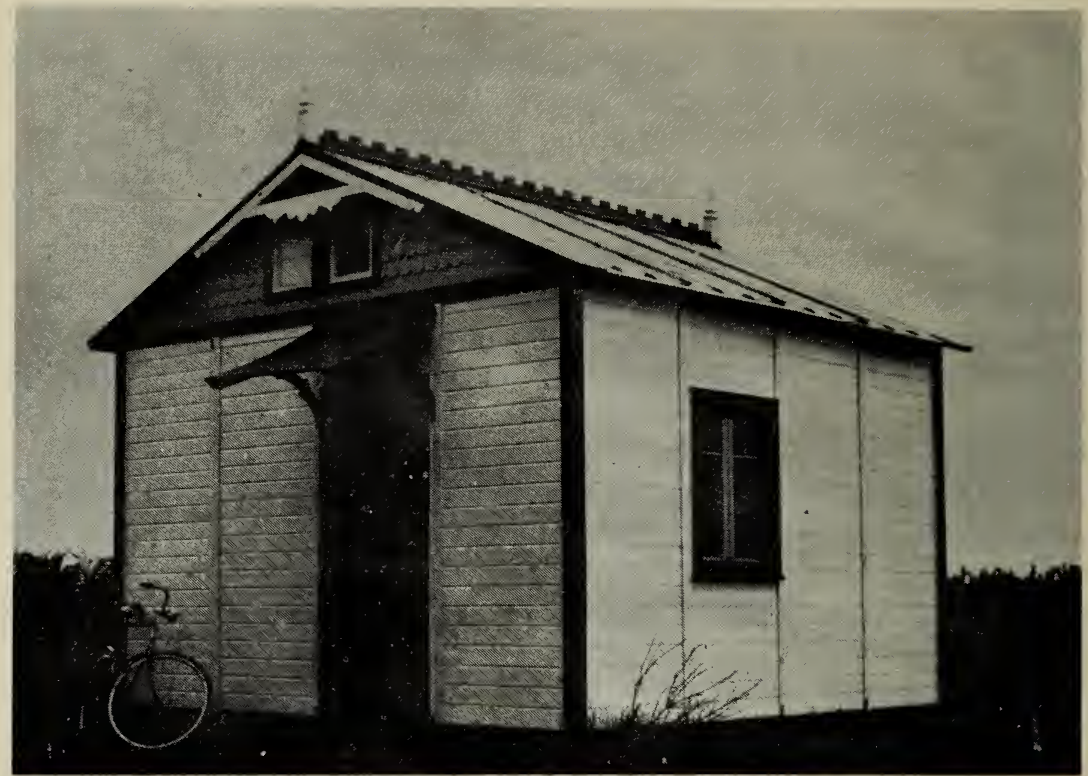

The first field laboratory of the Division of Plant Pathology at St. Catharines in 1911. Note the government vehicle.

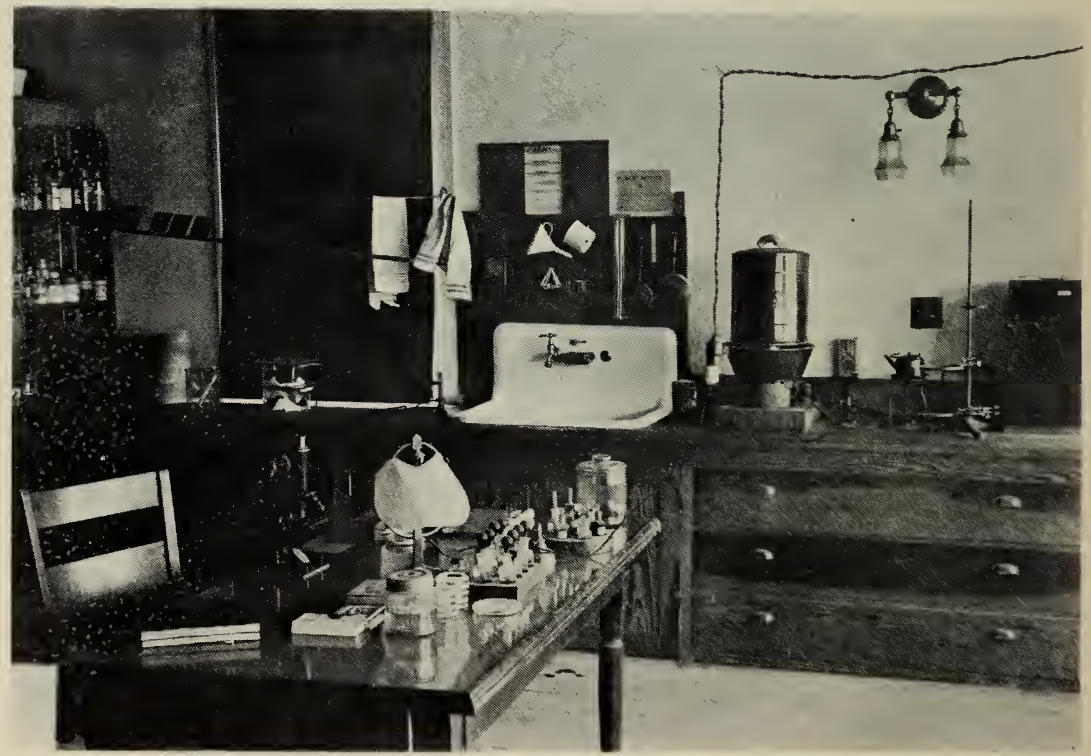

Interior of the second Plant Pathology Laboratory, built in 1914. 


\section{THE PLANT PATHOLOGY LABORATORY AT ST. CATHARINES}

\section{GETTING STARTED}

The first field laboratory of the Botany and Plant Pathology Division of the Experimental Farms Branch was established in a small portable shack on a peach orchard on the farm of Captain Robert Thompson, on Carlton Street, St. Catharines. This was in 1912. A year later, the Laboratory was moved to permanent and more commodious quarters in the top storey of the Merriman Block, on the south side of St. Paul Street, facing Academy Street. After a few years, a greenhouse was built behind the "Lab" on the roof of the projecting ground floor. This accommodation was reasonably satisfactory in the spring and fall, but was much too hot in summer and far too cold in winter.

\section{THE EARLY RESEARCHERS AND THEIR WORK}

Dr. W. A. McCubbin was appointed Officer-in-Charge of the new Dominion Laboratory of Plant Pathology. His first duty was to provide local growers with a more specialized extension service than hitherto obtainable. By 1915, after a fairly exhaustive survey of the district, he was able to publish a departmental bulletin, Fruit Tree Diseases of Southern Ontario, replete with the latest home-grown and imported information. Besides familiarizing himself with common local problems and working towards their solution, he helped to launch the Seed Potato Certification Scheme, and did a considerable amount of research on peach canker, then as now a serious problem in Ontario. A bulletin, Diseases of Tomato, and a paper on his canker work appeared in 1918, about the time he resigned to take up duties with the Pennsylvania State Department of Agriculture.

McCubbin's staff consisted mostly of college students, particularly during the war years. These Plant Disease Investigators were seasonally employed. This was a very useful practice as it gave the students, many of whom were doing post-graduate work, the opportunity to become acquainted with our projects and often led to permanent appointments. However, the grade fell into disuse in the mid-1930's and was replaced by the Student Assistant for undergraduates.

One of McCubbin's staff was G. O. Madden, who assisted with the work in peach canker and, after graduation in 1919, was first located at the Experimental Farm at Charlottetown. Another was Gordon Hunter. As Hunter specialized in Animal Husbandry at the Ontario Agricultural College, he admits that he was not especially well qualified as a Plant Disease Investigator. However, he soon learned to inspect potatoes for the Seed Potato Certification 
Service. This service had been set up in 1914 as a result of an American embargo on Canadian potatoes - on account of powdery scab - with a proviso requiring certification by Canadian government officials!

Hunter recalls being sent to the Brantford District before potatoes were even planted and to the Barrie district the day they were killed off by an unusually early frost - organizational growing pains, no doubt! His expense accounts must have been very closely scrutinized for, in those days, according to the Chief, the stub of the old pencil had to be turned in before a new one could be issued! On one occasion, to make up laundry expenses, Hunter charged 35 cents fare from station to hotel, but McCubbin, being familiar with the locale, disallowed the item on the grounds that the hotel was next to the station. In those days, too, time was cheaper than money, for regulations required the hiring of a horse and rig even when cars or taxis were available.

McCubbin was succeeded in 1918 by Dr. P. A. Murphy, who for some time beforehand had been working with late blight, mosaic, leaf roll and other diseases of potato, either at Ottawa or St. Catharines. These studies evidently laid the groundwork for seed potato certification. As Murphy published at least seven papers in this field between 1916 and 1921, it would seem that his interest lay more in research than administration, and he took charge only until the appointment of Dr. W. H. Rankin later in 1918. In any event, he was deeply involved in the potato studies and most likely chose to return to Ottawa in 1918 where experimental plots as well as better facilities were available. He remained in Canada until 1921, when he accepted an appointment in Dublin. It was probably about this time that the Laboratory was relieved of its share of the Seed Potato Certification Scheme.

Before coming to St. Catharines, Rankin had been studying the chestnut blight problem at Cornell. His book, $A$ Manual of Tree Diseases, was published in 1918. He undoubtedly took an active interest in the white pine blister rust campaign, at its height in eastern North America during his tenure of office. He also studied virus diseases of the raspberry and began to work on blue stem (Verticillium wilt) of the same host. Plans for certification of mosaic-free raspberry stock must have been broached at this time, as Rankin published an article on the subject in the Annual Report of the Geneva Experiment Station in 1923, within a year of his leaving the Laboratory. However, the scheme was not implemented during his regime.

J. F. D. Hockey came on staff in 1921 and, with Rankin, published two papers on mosaic and leaf curl (yellows) of the cultivated raspberry in 1922. About this time, too, the Spray Service was conceived, but during a gestation period of several years it took the 
form of a more or less haphazard advisory service, available on demand. When Rankin resigned to go to New York State in 1922, Hockey acted as Officer-in-Charge until the summer of 1923 and then went to take charge of the new Dominion Laboratory of Plant Pathology at Kentville, Nova Scotia. There he undertook studies in the control of apple scab, a project that was shared with the other Plant Pathology Laboratories of the Department until 1960.

\section{GROWTH IN THE MIDDLE AGES, 1923-1945}

The tremendous energy released for destruction during the First World War carried enough momentum to produce a post-war wave of creative activity in most walks of life, as well as the more spectacular Jazz Age and Flaming Youth of the Roaring Twenties. In the Division of Botany, still part of the Experimental Farms System, this activity took the form of a rash of Plant Pathology Laboratories spread across the country from the Atlantic to the Pacific and an ample fleshing of the skeleton staff of the war years. Incidentally, this had serious repercussions in the 1950's, when a corresponding rash of retirements broke out at a time when new professionel personnel were hard to come by. Being the firstborn, the St. Catharines Laboratory had to wait its turn, and expansion did not hit until after 1926, by which time a forceful personality had appeared on the scene to trigger the reaction. This was G. H. Berkeley.

The history of the St. Catharines Laboratory in this era and the next is, to a considerable extent, the history of this energetic Officer-in-Charge. Berkeley was born in Belleville, on November 30, 1894; he graduated in 1919 from Queen's under the aegis of Professor MacClement, one of the fathers of Canadian Plant Pathology; he took his doctorate at the University of Toronto, under Dr. J. H. Faull, with the thesis "Studies on Botrytis"; and he was appointed Officer-in-Charge at St. Catharines in 1923.

Berkeley's great contributions were in the administrative and organizational fields. His overwhelming ambition to make the Laboratory at St. Catharines second to none in the land was backed by his unflagging zeal and boundless energy, as well as his pugnacity and his persistent refusal to take "No" for an answer. His ability as a forceful and convincing speaker (even when not strictly accurate!) was another valuable asset both in fostering the growth of the Laboratory and in promoting its prestige and welfare. It was obvious to his colleagues that he identified himself completely with the "Institution," as he called it - or was it vice versa! At any rate, when he resorted to his familiar and favorite argument "for the good of the Lab." the rest of the staff soon learned to brace themselves for some sort of sacrifice or to be prepared to persuade him that their idea would better serve the same end. 


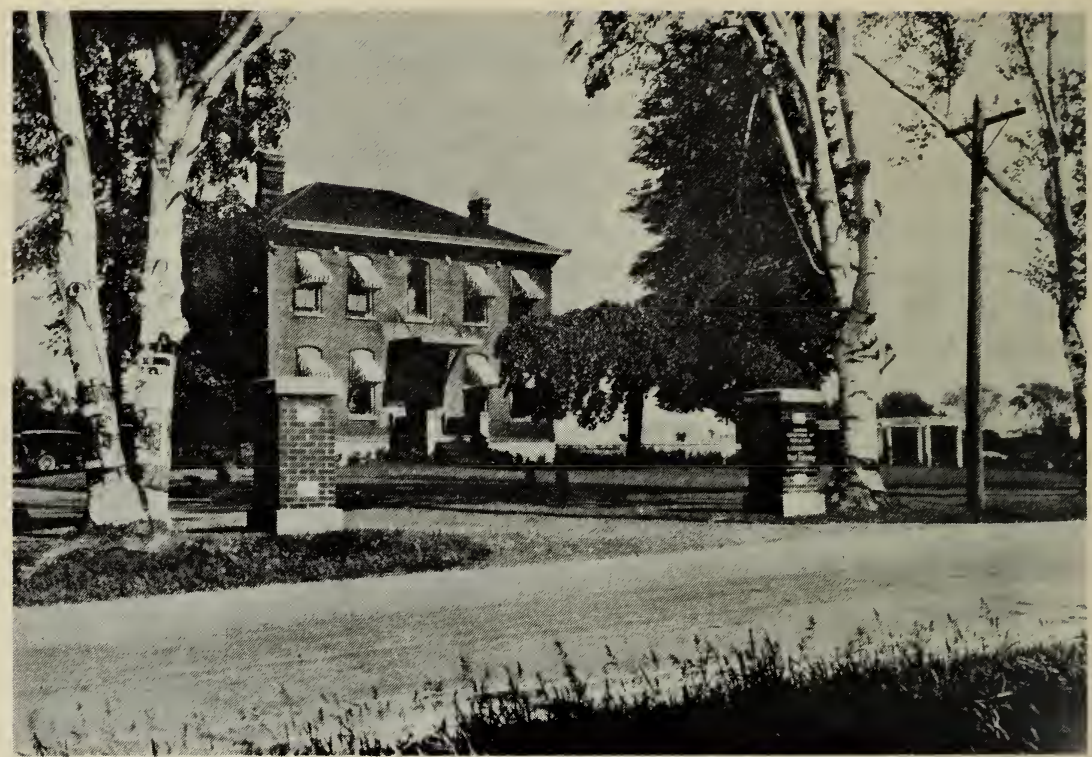

The house on the 32-acre farm at Niagara and Carleton Streets occupied by the Plant Pathology Laboratory in 1929.

\section{NEW FARM PURCHASED AND QUARTERS EXPANDED}

When Berkeley took over in 1923, he had only one assistant and the usual complement of summer Plant Disease Investigators. A second assistant came on staff in 1926. In the summer of that year, L. C. Coleman, newly appointed Provincial Plant Pathologist and first Professor of Plant Pathology at the University of Toronto, had temporary quarters at the Laboratory to begin his study of dead arm of grapes. The appointment of a third assistant in 1927 filled the laboratory accommodation to capacity. However, because of its location, there was no room for further expansion. Besides, land suitable for outdoor experiments was badly needed, as field work on plant diseases could not be done satisfactorily, if at all, on commercial fruit farms.

Thanks to Berkeley's initiative and energy, the Ottawa authorities were persuaded, probably not without some difficulty, to acquire in 1928 a 32-acre farm on the corner of Niagara and Carlton Streets on what were then the outskirts of the city. The City Fathers had bought the farm for a cemetery, but, as is often the case, they had since changed their minds and were willing to dispose of the land on very reasonable terms. This property would have been as suitable for the city's purposes as for ours, as it had a row of walnut trees about 100 yards back from Niagara Street, parallel to a row of 
beautiful white birches along the front, and a handsome row of European beech along the back fence. The walnuts had to be removed to make way for plots, but their ghosts haunted the place for a decade, so that plants grown in their stead did not flourish. Besides this interesting plant pathological phenomenon, the farm had a sturdy, 11-room brick house, built probably in the 1860's and eminently suitable for us. With the removal of only one partition in a closet, it was easily converted into a laboratory with six officelaboratories, a prep. room, a stenographer's office, a photographic studio and dark room, and two storerooms. These comparatively commodious quarters were ready for occupancy in 1929 and officially opened on June 30, 1930.

The previous occupant of the house had been a German farmer, who was accused of murdering his wife by putting corrosive sublimate tablets in the aspirin bottle in the medicine cabinet. He was acquitted, it being impossible to prove whether she had made a mistake in the dark or he had made a deliberate substitution. However, the odds were against him, as he was reputedly charged with a similar crime a few years later. In any case, the laboratory forever after had the reputation of being haunted by the unfortunate lady. In fact, John Batorski, one of the early hourly ratings, was so frightened after one tour of night duty that he quit the job next day rather than repeat the performance. Nick Vacarro, our Italian handyman, was made of sterner stuff. He did stick to night duty for three of four winters, in spite of seeing the lady pass through the furnace room walls, with a duck tucked underneath her arm, somewhat like Anne Boleyn. Nick, however, took precautions, in the form of a bottle of home-made wine, to fortify himself for his nightly ordeal. The laboratory was more than usually eerie after dark - enough so to unsteady the nerves of even the most sceptical and intrepid scientist who burned the midnight oil there alone.

Wine-making was one of the extra-curricular activities of some of the staff members. Nick Vacarro's efforts were by long odds the most extensive, sustained and generally successful, though some of our wives had trouble distinguishing his end-products from vinegar. Every fall, he bought up a vineyard with the express purpose of making more than enough wine to provide him with a gallon every weekday and two per Sunday. Nonabstaining members of staff each received a gallon of his best for Christmas. Berkeley's wines were much less voluminous than Nick's, and only slightly more potable. Memory suggests that he produced more and better fruit-flies than wine! Katznelson's ambition was to outrival Mme Brizard in the production of peach brandy. As he was not married at the time, his operations were carried out in Howie Phillips' cellar. The culmination of his efforts was a totally unplanned midnight fusilade of corks and a persistent odor of fermentation permeating Howie's home. 
A residence was built for the Officer-in-Charge in 1930, and cottages for the caretaker and the farm foreman in the late 1940's.

The original barn, besides being dilapidated, was unsuitable for our purposes and too close to the laboratory. In 1932, it was replaced with a metal drive shed, located closer to the back of the farm, to allow for a circular drive and irrigation plots behind the laboratory. The new shed was destroyed June 7, 1933, by the tornado that welcomed R. V. Harris on his arrival from East Malling to spend a year with us. The devastation embraced most of our row of white birch, cut a swath through the old peach orchard, uprooted a spruce on the front lawn, and gave Pete Newell a chance to practice tree surgery and cavityfilling on a horse-chestnut tree in front of the laboratory. Incidentally, the operation was highly successful and the chestnut, with cement filling, is still flourishing at time of writing, 33 years later. The drive shed was restored and enlarged later in the summer, and a barn-cum-packing house was built alongside in 1934.

In 1938, prospects for further expansion of personnel were rosier than during the depths of the Depression of "the dirty thirties" and plans were made for enlarging the building. The next year additions to the rear wing provided seven new office laboratories, an inoculation room, and a library-office. The two larger rooms on the ground floor of the new wing were used as temporary quarters for the Lincoln County Branch of the Victorian Order of Nurses during the war years. About this time, two insulated refrigerator rooms were installed in the basement for studies on storage and post-harvest disorders of fruits.

Attached to the laboratory proper were a small potting shed and a greenhouse of three 75-foot sections, built in 1928. A larger potting room, a room with four Wisconsin tanks, and a range of five small screened greenhouse compartments for virus studies, were added in 1935. Further additions to this range in 1945 and 1948 brought the total number of screened compartments to eleven.

At one end of the new potting room was a ramp to the basement and at the other the Wisconsin tank room. On one occasion the grandfather of all rats made his home under the potting bench along the north wall. Thence he raided the newly seeded pots in the various houses. After several futile attempts to get rid of the wily rascal with traps and poison, Nick Vacarro came up with a diabolical Borgian plot. He made friends with King Rat until he would confidently come out into the middle of the aisle to eat the remnants of Nick's midnight snacks. Then, one night, Nick lay in ambush on the ramp and shot his little pal with a 12-gauge shotgun loaded with BB's. The casualties were unintentionally numerous, like Marksman Sam's, and included the Rat, six panes of glass in the end wall of the tank room and half a dozen empty metal cans for the Wisconsin tanks. Next morning, we found the victim with a carnation in his crossed hands, lying in state on cotton batting on a chocolate-box coffin. 
As most of this era coincided with the Great Depression and the Second World War, funds were in short supply. There was even a year or so in the early 1930's when salaries were cut by 5 percent and then 10 percent. Equipment was hard to come by and carefully husbanded. The most sophisticated apparatus extended only to compound microscopes (sometimes fewer than one apiece), microtomes, an incubator or two and an autoclave - nearly all purchased before 1929. The field implements were horse-drawn, and part of the outside work, such as spraying and some of the pruning, was done by the research officer concerned. High-school students kept down the weeds with hoes, and technical assistance was not even dreamed of. Because of these restrictions and the many gaps in our knowledge of fruit diseases and their control, research was largely of the ad hoc variety, and was restricted to what could be done in orchard or greenhouse or within the limited scope of our laboratory facilities. As a result, we collected a good deal of information about infection cycles, modi operandi of pathogens, environmental factors and the like - all useful in devising workable control measures. Towards the end of the era, the St. Catharines Laboratory began to acquire an international reputation in the plant virus field.

\section{ROOT ROTS AND PLANT VIRUSES}

From the beginning, plant viruses and their importance ranked first in Berkeley's estimation. Well behind, in second place, came root rots. In 1933-34, Berkeley was in East Malling on exchange with R. V. Harris, who came to St. Catharines. In short order, a reverberating controversy sprang up. Harris was a strong advocate of viruses as the cause of degeneration of strawberries. Berkeley's curious but instinctive reaction was to champion root rot. Both, of course, were partly right.

In 1938, a plant pathology substation was set up on the Experimental Farm at Harrow, and L. W. Koch, who was working on brown root-rot of tobacco, went there so that he could work in the tobacco belt. By then, Newell, who was working on frenching of tobacco, was also spending some time at Harrow and nearby Delhi. Koch and Berkeley disagreed on the degree of autonomy to be granted the new substation, but by 1940 a new Dominion Laboratory of Plant Pathology had been set up with Koch in charge. Southwestern Ontario badly needed an organized plant pathological service, and the crops and problems there were quite different from those on the Niagara Peninsula.

To St. Catharines' great loss, Hildebrand was transferred to the new Laboratory in 1941. As he had no desire whatever for an administrative post and a deep and abiding interest in and a great ability for research, he and Koch complemented one another to the great benefit of the Harrow Laboratory, which soon became renowned for its studies in soil-borne and other diseases of field and forage crops. 
Thanks to Berkeley's fighting spirit and stubborn defence, root rots remained on the agenda at St. Catharines. For some years before he left, Hildebrand had carried on the strawberry root rot investigation from the point where Berkeley and Walker had left off. In 1939, Berkeley was instrumental in having P. M. West seconded to St. Catharines from the Division of Bacteriology at Ottawa, to study the bacteriological phases of the root rot problem. He was replaced in 1940 by $\mathrm{H}$. Katznelson, later head of the Microbiology Research Institute. When Hildebrand went to Harrow in 1941, his place on the team was filled by L. T. Richardson, now at the Pesticide Research Institute, London. About this time, J. W. Rouatt replaced Katznelson. When this team broke up in 1942-43, the project lapsed until after the war.

The work done at St. Catharines on virus diseases, particularly those of stone-fruits, won Berkeley world-wide recognition. In 1942, he was asked to work with E. E. Hildebrand of New York State and D. Cation of Michigan on a committee to compile an authoritative handbook on stone-fruit viruses. This book, published by the Michigan State Experiment Station, was remarkable as one of the first joint efforts involving many workers in the field who furnished not only published information, but also summaries of work in progress. Because of rapid developments, the handbook was revised and enlarged by the same committee in 1951 under the auspices of the United States Department of Agriculture. The revised handbook, which was compiled with the same generous cooperation as the first one, still remains the standard reference on the subject. In 1948, the British Government asked Walter Carter of the United States, J. G. Van Slogteren of the Netherlands and G. H. Berkeley to form a commission to visit Ghana (at that time the Gold Coast) and mediate between the West African Cocoa Research Institute, a Colonial Office organization, and the native cocoa farmers, who, under the influence of political agitators, rebelled against roguing and other remedial measures proposed by the Institute for the control of the swollen shoot virus. According to well-informed sources, these commissioners later became revered in Ghana as the Three Wise Men!

RENAISSANCE, 1946-1959

Soon after the end of the Second World War, the Dominion Laboratory of Plant Pathology at St. Catharines entered a second period of expansion, both in plant and staff. In 1948, the basement was enlarged to accommodate three air-conditioned rooms for growing plants under controlled temperature, humidity and light. These rooms were the first of their type to be installed in the laboratories of the Canada Department of Agriculture, and, though far from trouble-free, they have given good service up to the time of writing. In 1953, two laboratories with offices were built over the "growth" rooms for virology and microbiology. 
By this time, while considerable effort was still being directed to refining and improving control measures already worked out, emphasis tended towards greater depth in research, particularly in the fields of soil microbiolgy and virology. On the whole, though, a fairly healthy balance was maintained between "practical" and "basic" research. This change in approach became possible as equipment became more sophisticated and more readily available. Tractors and powered implements eased and speeded the work in plot and orchard. In the laboratory, a high-speed centrifuge, an electron microscope, spectrophotometers, chromatographic apparatus, and more claborate research microscopes enabled us to widen the scope and depth of investigation.

In 1948, the soil microbiology team was reconstituted with J. B. Robinson, of the Bacteriology Division, and Atkinson of our Laboratory. Study of the strawberry root rot problem was broadened to include a detailed investigation of the effects of the rhizosphere of the strawberry plant on the microflora of the soil, applying Lochhead's system of nutritional groupings to both bacteria and fungi. This team broke up in 1956, when Robinson left to join the Bacteriology Department of the Ontario Agricultural College.

In the late 1940's also, Berkeley organized a committee to direct a multipronged attack on the potato scab problem, with the Ontario Agricultural College, the University of Western Ontario, the St. Catharines Laboratory and the Provincial Extension Department participating. The role of the Laboratory was to study control by soil manipulation and amendment. The committee annually reviewed the various aspects of the project and made recommendations for the next year's work. As the committee was made up largely of nonparticipants with little more than a nodding acquaintance with the problem, the project suffered badly from well-intentioned misdirection - the usual fate of research by committee - and eventually foundered, leaving traces of results incommensurate with the effort put into the project.

Early in the 1950's, a laboratory study of the stone-fruit viruses was undertaken, with valuable results. Among the "firsts" in this field were the isolation and partial purification of the necrotic ring spot virus and the determination of its physicochemical characteristics and its unusual antigenic properties. Also, the approach to field studies of the stone-fruit viruses shifted from orchard surveys and host range studies to a search for possible vectors and parallel investigations on natural infection periods, the effects of distance from sources of infection on natural spread in new orchards planted with virus-free stock, the effects of virus infection at different stages of tree development, and the like. The research team demonstrated and proved that the necrotic ring spot and cherry yellows viruses are transmitted from tree to tree by means of pollen.

An intensive study of nematode problems in the Niagara district began in 1952. The many phases of the study, which is still 
going on, include the role of nematodes - alone and in complexes in the etiology of various root diseases, population studies, the weed hosts of some plant parasitic nematodes, and the longevity of these organisms.

Also in the early 1950's, diseases of greenhouse ornamentals started receiving a great deal of attention. The results of these studies have breen of great practical value to the trade, not only for improving control measures but also as a basis for devising procedures for quality control in the propagation of clonal lines. Advances have also been made in our knowledge of the viruses affecting carnations, geraniums, chrysanthemums and similar ornamentals all difficult hosts from which to extract virus.

\section{STAFF OF THE PLANT PATHOLOGY LABORATORY 1923-1960}

Berkeley's crowning achievement was the assembling of a strong staff of men with diverse interests and talents.

In spite of a creditable list of publications - some 23 scientific papers and numerous technical bulletins, pamphlets and articles Berkeley's own forte was not scientific research. It is only fair to say that he investigated many problems, but, partly because of temperament and partly because of administrative pressures, he was

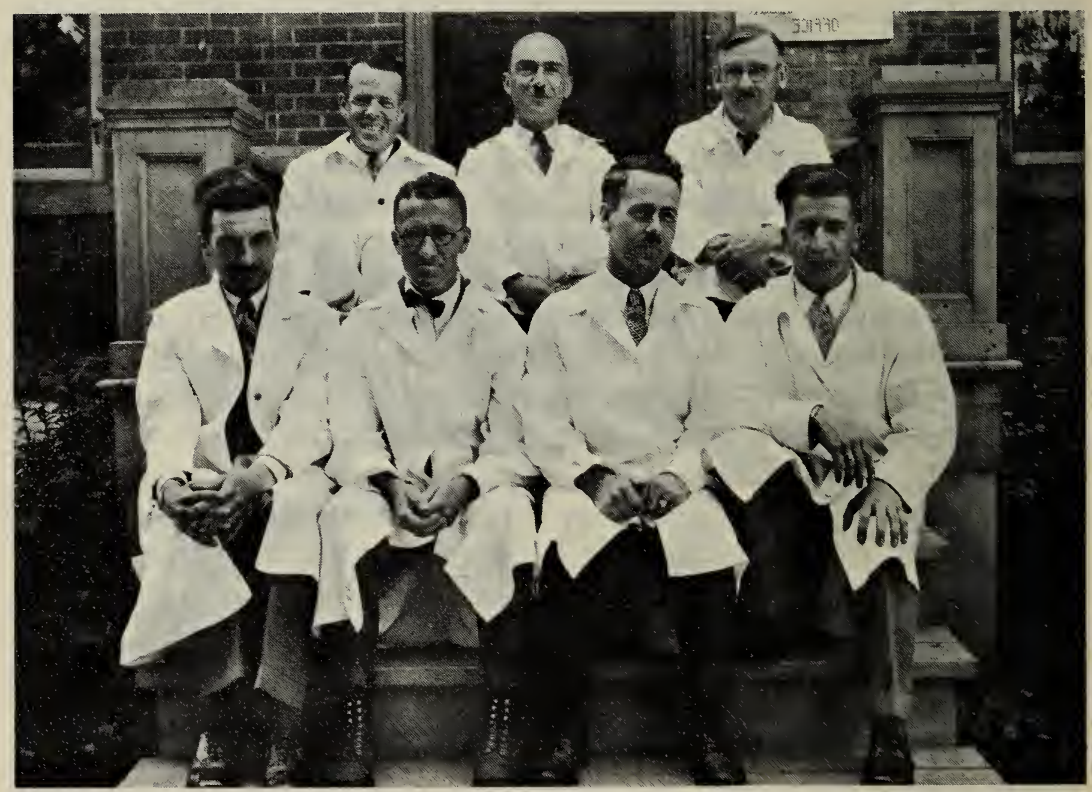

The professional staff of the Plant Pathology Division at the official opening of their new quarters in 1930. Back row (from left): G. O. Madden, G. H. Berkeley, G. C. Chamberlain. Front row (from left): L. W. Koch, A. R. Walker, J. K. Richardson and R. S. Willison. 
unable to give his research sustained attention. As a result, he usually lost interest in a problem after the bloom of novelty had worn off.

Strangely enough, though he was bold almost to foolhardiness in the executive and promotional fields, he was relatively timorous in research. Thus, the first reaction to any venturesome proposal was to apply the brakes, presumably on the grounds that that sort of thing had never been done before, so that there was little likelihood of anyone at the Laboratory succeeding. However, after due cogitation, he would usually come up with a very similar suggestion. We were never quite sure whether this type of reaction was due to a desire for credit for a new idea or to a wavering between disbelief and faith in the abilities of the staff, or both. However that may be, and greatly to his credit, faith nearly always won out. When he saw his support was justified, he granted it wholeheartedly and rarely interfered in any project unless it was going very badly.

Here, as elsewhere, the staff was divided into the "clockwatchers," who believed in and usually observed regular hours, and the "freewheelers," who thought that research could not be run by the clock. In all fairness, both groups gave the Department time in good measure, though, on balance, the freewheelers, not caring about time, were perhaps a shade more generous. The Officer-inCharge ex officio came down on the side of the clockwatchers and tried to enforce regulations literally. In the early years, he often greeted latecomers at the foot of the stairs, watch in hand, and oddly enough generally without verbal reproof.

G. C. Chamberlain came to the Laboratory as a student in 1924 and stayed until his death in 1963. His particular fields of interest were assessment of fungicides, stem blight and leaf spot of cherries, dead arm and mildew of grapes and virus diseases of raspberries. As senior member of the staff, he was Acting Officer-in-Charge during Berkeley's absences.

Chamberlain's field work in the Niagara Fruit Belt was of inestimable value both to the Laboratory and to the fruit industry. It was directed almost entirely to the solution of practical problems of great immediacy. That he wrote relatively few scientific papers was due less to the quantity and quality of his investigations, which were painstaking to a fault, than to the modesty and conservatism that made it difficult for him to satisfy himself, either that he had anything worth publishing or that he had sufficient evidence to challenge established theories. His forte lay in his thorough knowledge of fruit diseases and in the good common sense of his diagnoses and recommendations. Thus he earned both local and international repute as adviser, trouble-shooter and field-man par excellence. The same applied to his wide experience and encyclopedic knowledge of the practical applications of fungicides. In the early years, Chamberlain was responsible for developing and directing the spray service, and the certification of raspberry planting stock, including inspection. 
These two services were taken over by the Provincial Extension Service in the early 1940's. All through his career, Chamberlain held a key position on the Spray Calendar Committee, which annually reviewed and revised recommendations for pest and disease control.

Among the Plant Disease Investigators in the early years were A. B. Jackson (1921-1922), J. C. Perrault (1926), J. M. Hamilton (1927-1928), A. R. Walker (1928-1930), S. M. Pady (1929-1930), A. A. Hildebrand (1929-1932) and J. D. MacLachlan (1930-1931). Jackson became a regular member of the staff, working on bluestem of raspberry and Verticillium until 1928; and Perrault, who was on staff from 1927 to 1930 , concentrated on vegetable diseases and tomato viruses. Hildebrand, whose special interests were root rot of ginseng and strawberry, and virus diseases of strawberry, remained at the Laboratory until 1941. Hildebrand was one of the first to recognize the possible implication of nematodes and of root aphis in the strawberry root rot complex.

Another student in the early days who stayed on to make his career at the Laboratory was R. S. Willison. During his long service (1926-1965) he investigated a very wide range of problems: peach canker, brown rot of peaches, maturity, storage and post-harvest diseases of plums and peaches, and virus diseases of stone fruits. $\mathrm{He}$ also carried out host-range studies and physicochemical studies of viruses.

L. W. Koch spent the period 1929 to 1938 at St. Catharines working on spurblight of raspberries, black knot of plums and his main concern, brown root rot of tobacco.

When Perrault left in 1926, his place was taken by J. K. Richardson, who was to remain at the Laboratory until 1958. Over this long period, he investigated eggplant wilt, diseases of field tomatoes, late blight, blackheart, soft rot and tarnished plant bug injury, and aster yellows of celery, root rot of corn, black rot of turnip, storage spotting of waxed turnips and potato scab.

Richardson's outsanding characteristics, aside from his considerable professional abilities, were a bull-dog determination and a cast iron will - manifest in the set of his jutting jaw. In spite of the handicap of a rare and debilitating anaemia, he accomplished an astounding amount of work - witness the range of his projects. Also, in spite of warnings of the "impossibility" of the task, or perhaps in response to the challenge, he prepared the first Vegetable Protection Calendar, published in 1940, as a companion piece to the Fruit Spray Calendar. For several years he provided provincial fruit and vegetable inspectors with a service for diagnosing ring rot of potato.

$\mathrm{He}$ also had great mechanical ingenuity and devised, among numerous other gadgets, a vacuum suction apparatus for rapid plating of specified numbers of turnip seeds, a photographic illuminator, 
still in use, for eliminating shadows of specimens, and a home-made "nephelometer" for measuring the turbidity of liquid cultures.

A stroke and general deterioration in health forced his retirement in 1958 and, after a long, hard-fought battle, he died on March 21, 1960 .

G. O. Madden was in charge of greenhouses from 1928 to 1944. George was prone to a considerable degree of eccentricity, no doubt heightened by a boating accident, just before his appointment here, that necessitated spending the night on the bottom of a capsized dinghy. Thereafter he developed a pronounced phobia to drafts, and when he could be persuaded to accept a ride in a car, invariably tied a sweater or scarf around his waist to ward them off. He was even known, when working in the packing shed, to close the top half of the Dutch floor - leaving the large sliding truck door open!

At one time he was experimenting with methylene blue, his favorite color, in an attempt to improve the health and growth of seedlings. So great was his enthusiasm that he carried a solution of the dye in a test tube in his pants pocket. On the way home one night, his bicycle wheel caught in a street car track and he fell and broke his phial. As he felt the warm liquid trickling down his leg, he was sure he had severed a major artery. Closer examination showed that his "blood" was really blue. He also used to sleep with the phial under his pillow. One can well imagine what his wife said when the cork came out one night!

Madden was a kindly soul, but with a hot temper usually aroused when he was pushed into doing something he didn't want to do. At peach harvest, when assigned to feed the hopper of the grader, he often dumped the baskets from a great height, muttering highly colored imprecations, and hurled the empties into a corner. On another occasion, he had to do a hurry-up job potting tomato seedlings. As he picked up each plant, he raised it to eye level and vehemently denounced its morals and parentage before plunging it into the pot. When he caught pneumonia in August 1944, the poor fellow panicked when he heard what ailed him and passed away without a fight.

From 1933 to 1940 P. G. Newell filled various roles from seasonal farm foreman to research officer. He was a restless soul endowed with high spirits and a deep aplomb. For example, when the King and Queen came to the Niagara District in 1939, their motorcade was scheduled to pass in front of the St. Catharines Laboratory about 4 p.m., and the staff and their families entertained their opposite numbers from the Vineland establishments to a noonday picnic on the front lawn. As access to the royal route was closed off soon after noon, any activity on the street brought the crowd to its feet on the edge of the road. About 3 p.m. a car came speeding down from town, to be greeted with cries of "Here they come!" To the surprise of all, the car turned into the farm drive and Pete 
jumped out. He nonchalantly remarked that he had gotten through the police barrier by telling them that he worked for the King! After serving with the Canadian Army during the Second World War, he decided that research was much too quiet for him and so he undertook to promote tobacco growing in the sands of the Port Hope District instead.

J. R. Ferguson, a Student Assistant from 1936 to 1939, like Newell, served as seasonal farm foreman.

J. H. H. Phillips came to the Laboratory in 1937 to study the effects of nutritional deficiencies on virus-infected peach. He was away on military leave from 1942 to 1946, but on his return joined the Fruit Insect Laboratory staff and was seconded to St. Catharines to study the natural transmission and possible vectors of stone-fruit viruses. He took up his entomological studies again in 1954.

L. T. Richardson was with us for a year during the war (194142 ), working on root rot of strawberry. In the summers of the war years 1942 and 1943, we also had the valuable assistance of the Misses Ruby Allen and Hilda O'Keefe, who were seconded from the Seed Research Laboratory in Toronto to help as technicians and recorders.

After the war, newcomers gradually swelled the ranks of the staff, and many of them stayed on to direct the host of projects undertaken at St. Catharines in the 1950's and 1960's: K. M. Graham (19451950), seedling blight of asparagus; J. J. Miller (1946-1947), Fusarium wilt of muskmelon and segregation in Fusarium cultures; R. G. Atkinson (1946-1960), leaf spot of rhubarb and soil microbiology: the identification of soil fungi by nutritional grouping and other methods; W. G. Kemp (1947- ), damping off of seedlings in greenhouses, anthracnose of raspberry, blackspot of roses, fungus and virus diseases of greenhouse ornamentals - carnations, geraniums, chrysanthemums; J. D. Gilpatrick (1948-1951), chemotherapy of virus diseases, "immunity" and protection in virus diseases; M. Weintraub (1950-1959), physicochemical studies in stone-fruit viruses, physiology of virus infection (particularly local lesion infection), and chemotherapy of virus diseases; J. L. Townshend (1952- ), pathogenicity of nematodes in celery and strawberry, and host range and population studies in nematodes; J. H. Tremaine (1952-1964), serology and physicochemical studies in stonefruit and other viruses; J. A. George (on staff of Fruit Insect Laboratory, seconded to DLPP 1954-1962), vectors and natural transmission of stone-fruit viruses, field studies in virus diseases of stone fruits; T. R. Davidson (1954- ), field studies in stone-fruit virus diseases, and natural transmission of stone-fruit viruses; J. F. Bradbury (1958-1965), storage spot of waxed turnips, polybutene emulsions for the control of molds and mildews, and resistance to Verticillium wilt; H. W. J. Ragetli (N.R.C. Fellowship 1957-1958; on staff 1959), protection and immunity in plant viruses and physiology of virus infections. 


\section{AMALGAMATION OF VINELAND AND ST. CATHARINES LABORATORIES}

The organization of the Science Service within the Canada Department of Agriculture in 1942 and the attendant separation of the "scientific" divisions from the Experimental Farms Service affected the administration of the Laboratories on the Niagara Peninsula to some extent, but had little immediate effect at working levels. Each continued to go pretty much its own way and they remained geographically, administratively and psychologically separate.

However, amalgamation of the two Laboratories was considered for many years and finally took place. A 42 -acre farm at Jordan Harbour was purchased in 1958 with the idea that it would eventually replace the farm of the St. Catharines Laboratory, and plans were made for a modern building at Vineland to house the combined staffs of the two Laboratories. When Berkeley retired in 1959, they were formally united, with Dr. D. A. Chant being appointed the first Director of the New Research Station, Vineland, in 1960. So ended the 49-year and 48-year colorful lives of the Dominion Entomological Laboratory at Vineland and the Dominion Plant Pathology Laboratory at St. Catharines. 




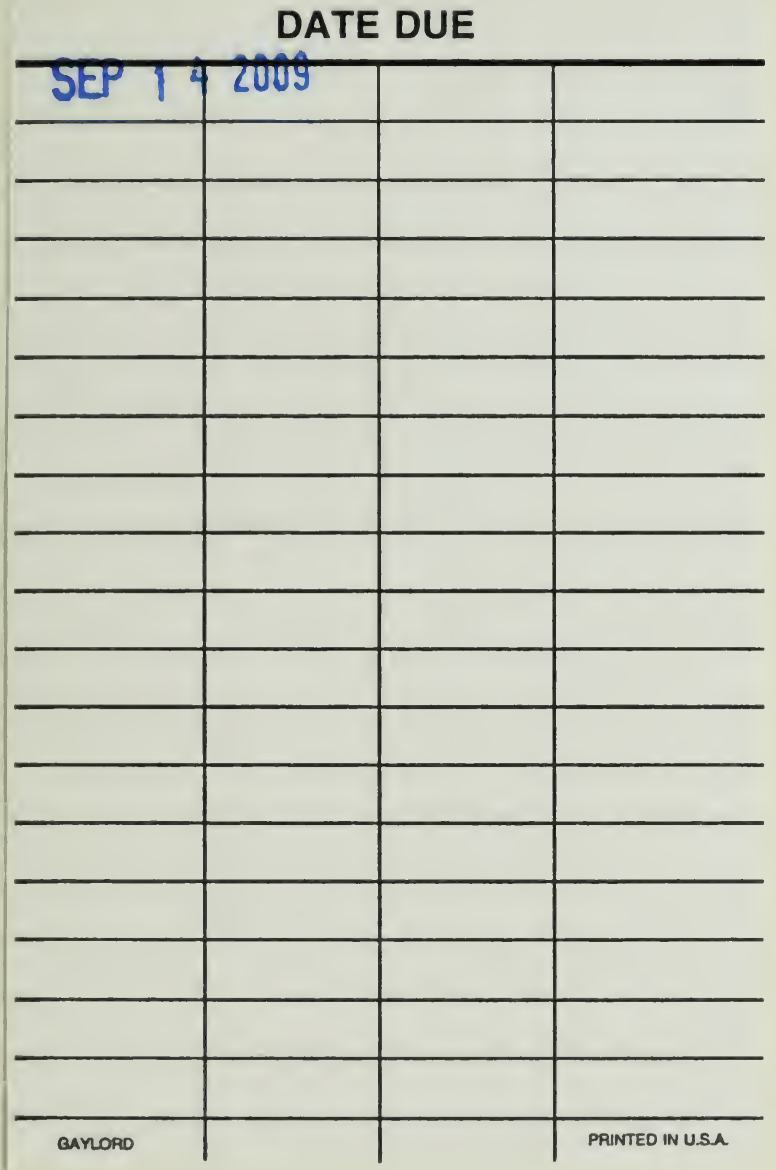


